\title{
Study on the Development and Current Condition of English Language Arts Education in Internet Age
}

\author{
Weixiang Liu and $\mathrm{Li} \mathrm{Li}$ \\ Science and Technology Institute of Nanchang University
}

Keywords: Internet; English; Education

\begin{abstract}
Contemporary information technologies with multimedia and internet as representatives are changing people's lifestyle and learning style at breakneck speed, which also lead to the networking-orientation, virtualization, internationalization and individuation of higher education in developed countries and regions. The internet provides spacious study space and rich resources for English learners. What's more, network English teaching can stimulate students' interests, add the chances for students to be exposed to English, which can provide beneficial conditions for students' self-directed learning. Internet brings along with a totally new concept for English teaching as well as new challenges. This paper discusses about the development and application of network English teaching, which comes to the conclusion that it can provide the environment for self-directed English learning.
\end{abstract}

\section{Introduction}

Nowadays, the learning ability of an individual has become a basic survival skill. Besides, the study on human's learning activities has become a front issue in multidisciplinary condition, which has made outstanding achievements in recent 20 years. However, the study does not include education theory and practice and as a result, the current learning approach, curriculum, education evaluation mode lag behind while students have low learning efficiency and cannot meet the requirement of times. More importantly, with the arrival of information era, people's survival style and learning style are experiencing a historical and huge change. However, the curriculums provided from primary school to universities do not cover the content to teach students' the skill to learn, and improve learning efficiency, especially the ability to develop and have high efficiency while learning in multimedia and internet environment. As a result, most of them cannot learn but deal with the examination, and become passive in self-directed learning atmosphere. Individual experience is not enough and only when students can understand and adopt the new development as well as results of the learning studies at home and abroad can they guide and improve themselves to become an outstanding learner who can keep the pace with times. Obviously, to apply modern information technology to carry out effective learning shall be basic knowledge and skill that English learners must have.

\section{Network English Teaching Mode}

Network English teaching mode should fully demonstrate its advantages and characteristics and emphasize that students are the main bodies in teaching activities, which to some extent can reduce the impact on teaching activities caused by teachers' personalities and ignite positive, interactive and open teaching mode. The teaching mode can adopt self-directed learning, collective learning and discussion learning.

Self-Directed Learning. Self-directed learning refers to the condition that learners can adopt the internet to consolidate and practice the knowledge and skills they have learned and learn new knowledge and skills, including listening online news, reading English stories and participate in online test etc. While carrying out self-directed learning, they have to choose proper learning materials based on their targets, and learning style to make proper schedule and plan. 
Collective Learning. Collective learning mode asks teachers to prepare the teaching materials in advance and demonstrate the materials based on multimedia, which should cover text, shape and sound so as to have interaction.

Discussion Learning. At present, there are various English learning discussion groups online, including groups for CET 4, CET6, EST learning group, English translation group and English writing group etc. This kind of learning modes can be adjusted based on the interest and personalities of learners.

\section{Challenges Brought by Network English Teaching}

There should be a process from traditional education to network education and only when we positively face the impact brought by internet, maximize global resources to advance and adjust the teaching system, program and plan can we better serve the education with network.

Network English Teaching's Demand for Teaching Method. The social resources sharing advocated by the network meets the demand of modern education, while network teaching has already become a good solution to cover the gap of modern education resources. The teaching mode with reviewing as the focus will be replaced by interactive and intelligent question-answering and case teaching.

Network English Teaching's Demand for English Teachers. The implementation of network English teaching has made higher demand for teaching design. Teachers have to carry out a series of feasible design for teaching objectives, contents, students feedback and teaching evaluation etc or there should be extensive management. The task of teachers is to cultivate students' ability to analyze problems and solve problems, to think from multiple perspectives and adopt foreign language to carry out intercultural communication to finally achieve quality education.

Network English Teaching's Demand for Teaching Mode. Network English teaching is a self-directed teaching mode with students as the center, which digitizes the teaching contents and stores the contents in the server. Therefore, students can carry out self-directed learning and those who have extra time can learn fast while those who have a slow schedule can learn slowly and should not be afraid of keeping up with the teaching arrangement.

\section{Network English Teaching Countermeasures}

Update Ideas and Increase Investment. Learn from advanced and pilot units, take education information construction as a powerful means to promote the modernization of education, carry out overall planning and development of important regions, speed up the broadband network access. Besides, the gradual application of informationization in teaching amen management has exerted a positive effect on promoting education fairness and bridging the digital divide, which will also promote the progress of education modernization.

Integrate Resources, Act With United Strength. Network English teaching is not only related to English teaching but also the internet and the whole society at large. First of all, network English teaching should be tackled in the way of education industry and encourage more businessmen, industries, media and educators to participate in the competition so as to optimize the resource allocation.

Multinational Cooperation, Work Together in the Future. Concerning the network education, the hardware as well as platform construction of foreign countries are advanced and therefore import intelligence and capital has become a short cut for Chinese network English development. At present, Chinese educational departments should mutually develop relative software and resource base with foreign enterprises and institutions to share resources, rich teaching contents so as to fully perfect the current assessment and evaluation system. 


\section{Conclusion}

From a global point of view, network English teaching, as a new teaching and learning means is not confined to time, space and resources, which to some extent narrow the gap of urban and rural education resources. It is flexible with various means, with a large space for teachers and students to choose. In the future, it will become the mainstream and backbone of English teaching. What's more, it will undertake a heavy burden in the new time yet with a prosperous future.

Looking into the network English education in China, educators should clearly recognize that it starts behind with a weak base. However, with the assistance of the rapid developed economic and information technology, China will inevitably establish a network English teaching mechanism which accords with the Chinese actual condition and thus open up a new prospect.

\section{References}

[1] Scoon A R. Affective Influences on English Language Learning Among Indian Students.[J]. Tesol Quarterly, 1971(4):N/A.

[2] Gilakjani A P. The Significant Role of Multimedia in Motivating EFL Learners' Interest in English Language Learning [J]. International Journal of Modern Education \& Computer Science, 2012, 4(4).

[3] Ann Matear. English language learning and education policy in Chile: can English really open doors for all?[J]. Asia Pacific Journal of Education, 2008, 28(2):131-147.

[4] Bessie Mitsikopoulou. The Interplay of the Global and the Local in English Language Learning and Electronic Communication Discourses and Practices in Greece [J]. Language \& Education, 2007, 21(3):232-246.

[5] Flores E, Painter G, Harlow-Nash Z, et al. Que Pasa?: Are English Language Learning Students Remaining in English Learning Classes Too Long? Policy Brief. [J]. Tomas Rivera Policy Institute, 2009:4.

[6] Saidi A A, Al-Mahrooqi R. The influence of gender on Omani college students' English language learning strategies, comprehension and motivation [J]. International Journal of Applied Linguistics \& English Literatur, 2015.

[7] Kimura Y. English Language Learning Motivation: Interpreting Qualitative Data Situated in a Classroom Task [J]. Arele Annual Review of English Language Education in Japan, 2003, 14:71-80.

[8] Ghasemi B, Hashemi M. ICT: Newwave in English language learning/teaching [J]. Procedia Social and Behavioral Sciences, 2011, 15(15):3098-3102.

[9] Murray D E. Creating a Technology-Rich English Language Learning Environment [M]// International Handbook of English Language Teaching. Springer US, 2006:747-762.

[10]Gömleksiz M N. An evaluation of students' attitudes toward English language learning in terms of several variables [J]. Procedia - Social and Behavioral Sciences, 2010, 9:913-918.

[11]Abedi J. Validity of assessments for english Language learning students in a national/ international context [J]. Ese Estudios Sobre Educacion, 2009, 27(16):167-183.

[12]Meyer X S, Capps D K, Crawford B A, et al. Using Inquiry and Tenets of Multicultural Education to Engage Latino English-Language Learning Students in Learning About Geology and the Nature of Science[J]. Journal of Geoscience Education, 2012, 60(3):212-219. 